\title{
THE UNINTENTIONAL CREATION OF A JOINT TENANCY IN THE CONTENTS OF A SAFE DEPOSIT BOX.
}

A dangerous pitfall for the unwary layman has arisen from the creation of an unintended joint tenancy as to the contents of a safe deposit box by the sigming of variety of a joint rental card-more or less foisted upon co-lessees at the instance of some bank clerk or vault manager in the safe deposit vault department of the bank.

When persons apply to the safe deposit department of a bank and ask to rent a box in their joint names, they are presented with a form of agreement with the bank as to the manner in which they are to lease the box. Although the box is referred to as being "leased", the relationship created between the bank and the renter in California and the majority of states is one of bailee and bailor rather than that of lessee and lessor. ${ }^{1}$ If the lessees want to lease a box jointly, having an equal right of access to and ownership of the box, they must sign a joint rental card. ${ }^{2}$ These joint rental forms vary with the different banks in the absence of a statute requiring uniformity.

There seem to be two principal forms of joint rental agreements. The first and most commonly used type states in substance, that the co-renters shall each have access to the box without the presence of the other; that each shall have a key; and that upon the decease of one of the parties, the survivor has the right of access to the box, or the right of access to and possession of the contents of the box. ${ }^{3}$ Sometimes this contract is labeled "joint renters with the right of survivorship". Many bank representatives refer to this as a "joint tenancy card". However, it will be referred to herem as a "joint access card".

The second type of co-renters card besides using the same language as the joint access card, also stipulates that the renters are jomt tenants as to all of the property in the box and that the title or the right of survivorship will vest in the survivor. ${ }^{4}$ This form will be referred to as a "joint tenancy card", for it has been held to create a true joint tenancy in the contents of the box. The joint access card

1 See Webber v. Bank of Tracy (1924) 66 Cal. App. 29, 225 Pac. 41; Cussen v. Southern Calif. Savings Bank (1901) 133 Cal. 534, 65 Pac. 1099; Tacoma Park Bank v. Abbott (1941) 179 Md. 249, 19 A. (2d) 169. But see to the contrary that the relationship of lessee-lessor is created. Tow v. Evans (1942) $194 \mathrm{Ga} .160,20 \mathrm{~S}$. E. (2d) 922.

2 Also if two or more persons desire to rent the box in an official or business capacity rather than their individual capacities, they may sign a business form of card such as the following forms (differing with the various banks): principle and agent (i.e., a deputy card), corporation, or partnership card.

3 For an example of joint access card, see Security-First National Bank v. Stack (1939) 32 Cal. App. (2d) 586, 90 P. (2d) 337.

4 For an example of joint tenancy card, see Young v. Young (1932) 126 Cal. App. 306,14 P. (2d) 580. 
has been expressly held not to make the lessees joint tenants as to the property therein.

It may also be noted that there is sometimes used a third type of card. This contract merely states that the undersigned parties are co-renters of the box. It says nothing concerning the right of survivorship. There has been no litigation in California concerning this third form. It cannot possibly be supposed that it would create any joint tenancy in the contents of the box.

As to the two principal forms of -joint rental cards, the law in California is seemingly clear as to the effect of signing the agreement upon the title to the property placed in the box. There is, however, more or less, a prevalent delusion in banking circles, that both types of cards create a joint tenancy. Two types of litigation arise out of these agreements: one is between the surviving tenant and the representative of the heirs of the legatees of the deceased joint tenant; ${ }^{5}$ the other is between the bank and the representative of the heirs or legatees of the deceased tenant. ${ }^{6}$

\section{JOINT ACCESS CARD}

Security-First National Bank of Los Angeles vs. Stack is the only, California case interpreting the effect of the joint access card upon the contents in the safe deposit box. This is an appellate court decision and the question involved has never gone to the supreme court. In this case a husband and wife rented a joint safe deposit box. In so doing they signed with the bank a joint access card, which read "right of access and possession of contents thereof" to the survivor. The husband subsequently passed away testate. The wife elected not to take under the will and contested the declaration therein that all of the property of the spouses was community property, upon the basis that the card signed made them joint tenants as to the securities and contents of the box. Therefore, she claimed all of that property by right of survivorship. The district court of appeal denied her claim, reasoning that the right of survivor to have access and possession did not render the parties joint tenants as to the contents of the box, but merely made them joint tenants as to the lease. No cases nor statutes were cited by the court as authority. This was a sound decision, for nothing was said in the agreement as to title. Right of possession must clearly be distinguished from ownership. One can have the right to possess property and still not hold the legal title.

5 For example, see Kirwan's Administrator v. Citizens Union National Bank (1927) 222 Ky. 65, 299 S. W. 1104.

O For example, see Estate of Gaines (1940) 15 Cal. (2d) 255, 100 P. (2d) 1055.

7 Supra note 3. 


\section{Other State Decisions}

In the early New York case of In re Brown, ${ }^{8}$ the court held, in accord with the Stack case, that the signing of a card giving the surviving spouse right of access, did not create a joint tenancy in the property in the box. Other states have reached a similar result, but New York is the only state that decided the case before the court upon the same ground as the California court, i.e. upon the basis of the language that was used in the card. The Rhode Island court in Millman $v$. Streeter ${ }^{9}$ regarded the joint access card as only one factor in its decision. The court also found that the conduct of the parties was at variance with a true joint tenancy; and above all, that the bank was not a conduit through which the title to the contents of a safe deposit box, which it leased, could be transferred from one tenant to another. The Missouri case of Napier $v$. Eigel, ${ }^{10}$ although it does not involve the signing of a joint rental card, is in point in reference to the factors which the various courts will weight in determining if a joint tenancy has been created. In that case, the decedent had endorsed on an envelope in her safe deposit box "Emergency property of (decedent) or (survivor)". 11 The survivor claimed the contents of the envelope, but the court held that there was not sufficient proof that a gift had been completed. It also required some change in the character of the possession from that of sole owner to cotenant. In the Illinois case of In re Jirovec's Estate ${ }^{11}$ the court based its decision upon the technical ground that the words used in the joint access card, "either/or the survivor" to have access to the box did not create a joint tenancy, because the words either/or destroyed the essential requirement of unity of possession. The Pennsylvania court in In re Wohleber's Estate ${ }^{12}$ held that the fact that property is found in a safe deposit box leased jointly may raise a presumption of ownership, but here this presumption was overcome by sufficient evidence of ownership in another. Again, the fact that the words either/or were used in the rental card was a stumbling block to the survivor's claim to the contents of the box. However, the Michigan court has held in the case of Lilly $v$. Schmock ${ }^{13}$ that because of the use of the words "either or survivor" a joint tenancy in the contents was created, although only a joint access card was signed. In this case, the decedent and his survivors had first rented a box signing a deputy or agency card. Subsequently, the decedent changed the form of card,

8 (1914) 149 N. Y.S. 138, 86 Misc. Rep. 187.

0 (1941) 66 R.I. 341,19 A. (2d) 254.

10 (1942) 350 Mo. 111, 164 S.W. (2d) 908.

11 (1936) 285 Ill. App. 499, 2 N.E. (2d) 354 ; see Note 113 A.L. R. 573 at 575.

12 (1935) $320 \mathrm{~Pa} .83,181$ Atl. 479.

13 (1941) 297 Mich. 513, 298 N. W. 116. 
obtaining a joint access card with his former deputies, giving all lessees the right to enter and remove the contents after decease of the other lessee. The court held that because the decedent had changed his form of rental card, he showed a definite intention to make his co-lessees joint tenants in the contents of the box, for the new card used the words "either or the survivor". It is interesting to note that practically all of the joint rental cards in California use the words either/or, yet this has never been considered a decisive factor, nor even an element in the case worth mentioning in this state.

The Massachusetts court, also, has held contrary to the Stack case. In the case of Graham v. Barnes, ${ }^{14}$ the decedent, a 60-year-old man, had leased a joint box with a woman friend. They signed a joint access card. In the box he placed valuable bonds which were his separate property. The court held that on his decease his friend was entitled to the bonds by the right of survivorship, that the card had made the renters joint tenants as to the contents in the box. No distinction was made between access, possession, or ownership.

\section{Liability of the Bank}

As for the liability of the bank, it has never been decided in California whether the bank would be accountable for allowing the surviving renter of the box to take possession of the property of the decedent, were he to abscond with it. The banks contend that they would not be obliged to the representatives of the decedent's estate because the tenants had signed a contract permitting joint access. The arguments opposed to this contention are that the relationship of bailee-bailor exists, putting some duty of care upon the bank and that contracts against negligence are against public policy. In the case of Kirwan's Adm'r v. Citizens' Union National Bank, ${ }^{15} \mathrm{Ken}-$ tucky, two sisters had contracted for a joint box, with the survivor to have the right to enter. The surviving sister ran off with $\$ 3200$ in bonds belonging to the decedent. The administrator of the decedent's estate sued the bank on the basis that the contract was illegal. The court held that it was a good contract between the three parties, that it did not violate public policy, and that it was an exercise of the right of freedom of contract. The bank was held to be not liable. The Kansas court has held likewise. ${ }^{16}$ There are no cases holding the banks responsible in this situation. The above Kentucky and Kansas cases are apparently the only decisions on the subject.

14 (1927) 259 Mass. 534, 156 N. E. 865.

15 Supra note 5 .

16 Rankin v. Gough (Mo. App., 1928) 6 S.W. (2d) 640. 
District of Columbia, ${ }^{17}$ Michigan, ${ }^{18}$ Montana, ${ }^{18}$ and Texas ${ }^{20}$ all have statutes which authorize banks to use the joint access card. Both the District of Columbia and the Texas statutes stipulate that the banks shall be exempt from liability when they use this form of card. The Michigan statute, alone, solves the principal problein that we are considering, by stating expressly that the joint access and possession card which it authorizes does not have the effect of changing the title of property placed in the box.

\section{JOINT TENANCY CARD}

There are only two California cases which hold that a joint tenancy arises from the mere designing of a joint tenancy card when leasing a safe deposit box. Both of these cases went before the supreme court. The first case, Young vs. Young, ${ }^{21}$ was decided in 1932. The second, In re Gaines, ${ }^{22}$ was decided in 1940. In the Young case, a husband and wife, when leasing a safe deposit box jointly, signed with the bank an agreement, stipulating that: "We hereby declare that all the contents of said safe now or hereafter placed therein, are our joint property and that title and right of survivorship thereto and to the whole thereof rests in the survivor of us as his or her separate property". Nevertheless, the husband executed a will. Upon his decease, the wife contested the validity of the will so far as it referred to the property in the safe deposit box. She contended that by the agreement the property was held in joint tenancy. The court upheld her claim, that once property was put into the box, it was jointly held subject to the right of survivorship. Thus, the husband's will was moperative as to the contents. The decision was based upon the statutory ground that the husband and wife had the right, as between themselves, to enter into any agreement respecting their property. Although a written agreement was before the court, the parol evidence rule was not mentioned; but the court reached the result of limiting the evidence to the face of the contract, by stating that "it is not necessary to travel outside of the facts of this case". The court opined that the parties knew what they were doing and wished to accomplish and that the husband was fully aware of what his act meant under the terms of the agreement. However, this raises a query: if, as the court says, Mr. Young knew the significance of his act, then why did he think that he could still will his property away?

\footnotetext{
17 D. C. CODE (1940) $\$ \$ 26-202$.

18 Public and Local ACTs-Michigan (1939) No. 330 (23.1123).

19 Laws, Resolutions and Mearorials-Montana (1939) c. 62, §1.

20 Tex. Stat. (Vernon, Centennial ed., 1936) art. 541e.

21. Supra note 4.

22 Supra note 6 .
} 
The court stated that "between themselves the parties had the right to make this agreement. It must therefore be considered a binding agreement between them."

The opinion did not consider the strange result whereby merely signing a written agreement for a box in a safe deposit vault changed the character of all property once placed therein. In fact, it did not even refer to the "agreement" as a rental card. In banking circles, however, this decision caused much confusion. It is known that at least one of the larger Northern California banks which had used rental cards similar to that used in the Young case, immediately sent out a letter to the joint lessees of its safe deposit boxes, warning them that the title to their property had changed, advising them to consult their attorneys, and offering them a different type of lease to sign. Moreover, the Safe Deposit Bulletin, which is a monthly publication edited by the Safe Deposit Society of New York, mentions the bewilderment brought about by the case. The bulletims contain the published review of the regular and convention meetings of the vault managers. Hardly a year has gone by without someone, member or guest speaker, criticizing the Young case. Nearly every speaker has a different reason for disagreeing with the case. One member said that there was so much confusion upon the subject that he did not think it would be worth while publishing the discussion (about joint tenancy cards).$^{23}$ After the Young case a few of the banks began to change their forms of rental agreements.

Although the testator's intention to pass property by his will was defeated, the actual consequences of the judgment did not work an undue hardship to those involved, for the property had been acquired by the spouses subsequent to the marriage and thus partially belonged to the wife anyway. The application of this reasoning, however, can work a great injustice when the relationship of the parties is more remote, as illustrated in the case of In re Gaines. ${ }^{24}$ There the decedent and his grandnephew, the appellant, leased a joint safe deposit box, signimg a joint tenancy card. It was really the decedent who took out the box and all of the property placed therein was his own separate property. The grandnephew did not keep a key to the box and never used it for his own purposes. Here, neither party realized the survivorship rights of joint tenants, for the uncle executed a will and the nephew continually expressed the opinion that his uncle did not intend to make a gift of the property to him. He thought that the deceased's purpose was to provide for convenience of access in the handling of the estate, of which the appellant had been made co-

23 Safe Dep. Bul., June, 1944.

${ }^{24}$ Supra note 6 . 
executor. It was not until one year after his great-uncle passed away that the appellant claimed a gift of the property to him as joint tenant and demanded the rights of a survivor. The estate, in attempting to prove its case, was confronted with the parol evidence rule. As the court stated: "The rule comes into operation when there is a single and final memorial of the understanding of the parties. (Here the rental card) "When that takes place, prior and contemporaneous negotiations, oral or written, are excluded ... in the absence of fraud, or due to influence, or an unsound mind." The court, however, recognized an exception to the parol evidence rule, that the estate could prove that the property passed to the appellant in trust. ${ }^{25}$ The theory accepted was that an agreement collateral to the main writing can still be introduced to show the purpose of the contract. This put upon the estate the burden of establishing a definite trust in the grandnephew to hold the property for the benefit of the legatees. The estate's evidence consisted inainly of statements of the appllant to the effect that his uncle did not intend to give hin the property, which statements were excluded upon the ground of hearsay; that he did not "feel" he had any claim to the property. Also, it introduced a letter delivered to the grandnephew after his uncle passed away. It stated, in substance: "Enclosed please find the key to my safe deposit box ... , which is in our joint names, said box contains most of my securities, ... from my bank account which is in the name of my wife and self .... You can immediately get in touch with ... coexecutor and start work on settling the estate". In spite of this letter, the court held that although it recognized that evidence was introduced which tended to establish that the intent of the joint tenancy might be for "convenience" in "care" of the estate, there was not sufficient evidence to establish the exact purpose of the trust, and so the trust could not be proved.

The court regarded as highly persuasive evidence proving decedent's knowledge of the legal effect of his acts, the uncontradicted testimony of the clerk in the safe deposit vault who leased the box to the decedent. She testified that she asked the decedent whether he wanted the appellant to sign as agent or whether he wanted a joint ownership contract; and that he selected the joint ownership form. Also, as part of her regnlar duty she explained that upon the decease of one of the parties, the contents belonged to the survivor. The court held that consequently the deceased intended to create a jomt tenancy. The court did not refer to the fact that those were the only two types of rental cards that the bank offered the decedent. If he had taken the agency forn, his grandnephew could not have had access to the property so that he could have the funds in his possession 
to start managing the estate. The judgment was that the nephew took all of the property in the box to the exclusion of the legatees under the will.

\section{Parol Evidence Rule}

If it can be shown that the interest of surviving co-depositor of funds in a bank account opened in the name of both parties was intended to be impressed with a trust, ${ }^{26}$ or that a joint tenancy in the contents of a safe deposit box was intended as a trust, as an exception to the parol evidence rule, it would seem to follow that it may be shown that the signing of a joint tenancy card in a form creating apparently a joint tenancy of the contents, was not intended as a gift of his property by a depositor who places securities, etc., in the box. ${ }^{27}$ It should be possible to show that the signing of a joint tenancy card was intended as a mere matter of form for convenience without donative intent and to create a kind of agency for the benefit of an undisclosed principal for convenience in the administration of his estate. ${ }^{2 s}$ If such a showing of the intention of the parties is not allowed a great injustice may be done the parties by the mechanical application of the vague parol evidence rule which will impose great hardship on mnocent parties by reason of a formal method of doing business and will create harmful results not contemplated by them. Otherwise one moment's deposit of securities by an owner in the magic box will transfer an interest in joint tenancy to the other parties even though the securities be almost instantly removed by the depositor and sold to others.

The object of the bank or safe deposit department in urging the inclusion of a joint tenancy agreement in its safe deposit contracts where several persons are to have access to the box is obviously to protect itself from possible liability for negligence in supervision in permitting the withdrawal of the contents by an unauthorized person, particularly in event of the death of one of several co-lessees of the box. It is usually not the aim or desire of the co-depositors in the box to create a joint tenancy as to the contents. They sign an agreement to this effect simply as a matter of form in order to comply with the demand or request of the bank.

It should be possible to show by parol evidence that the effect of this agreement is intended simply to grant the bank the same immunity from liability for negligence as custodian which it would

25 See 9 Wigmore, Evmence (1940) §2437; 3 Wuliston, Contracts (1936) $\$ 635$.

20 In re Kellogg (1940) 41 Cal. App. (21) 833, 107 P. (2d) 964; Randall v. Bank of America (1941) 48 Cal. App. (2d) 249, 119 P. (2d) 754.

27 See Note (1944) 149 A. L. R. 879 at $880-888$.

28 See Note (1944) 149 A. L. R. 862. 
have if the co-depositors were joint tenants with right of survivorship, in which case the survivor would have the right of withdrawal.

As between the co-depositors a creation of a joint tenancy in the contents of the box should depend upon an actual intention of one depositor to make a gift to the other depositor. This intention must exist at the time of the deposit in the box. There should also be something that is equivalent to a delivery to the donee as a manifestation of this intent. A deposit in a box from which the depositor has the right of instant withdrawal at any time without notice to the alleged donee is not such a surrender of dominion or manifestation of mtention to give as would ordinarily be sufficient to transfer an interest by way of gift to the other depositor who knows nothing about it.

\section{Statutory Authority}

As authority for its decision, the court relied completely on the Young case, stating as the doctrine of that case that "the joint tenancy cards signed by the parties with reference to both the safe deposit box and the bank accounts would, standing alone, be sufficient. to create joint tenancies, that is, joint interest with right of survivorship to the whole". However, the Young case rested upon the right. of a husband and wife to contract between themselves as to theirproperty. There was no discussion of any gift, nor trust, nor effect of a joint tenancy safe deposit box rental card. Today, by statute in. California, a sole owner can make another his joint tenant in per-sonal property by written or oral agreement, ${ }^{29}$ but this statute was. not in effect at the time of either the Young or the Gaines cases.

\section{Decisions of Other States}

In the case of In Re Koester's Estate ${ }^{30}$ the appellate court of Illinois held in accord with the Gaines case that an agreement exe-cuted by joint lessees stating that they were joint tenants of the contents of the box with right of survivorship entitled the survivor to. the property therein. It is interesting to note that an Illinois statutehad abolished the right of survivorship, "unless ... reserved by will or other 'instrument' ... . The court held, that this was such an in-strument, and so the claimant was even able to get around the strict. legislation. In the New York case of Mercantile Safe Deposit Co. v. Huntington, ${ }^{31}$ the court held that the joint tenancy card merely gave-

29 CAX. Crv. CODE $\S 683$.

30 (1936) 285 Ill. App. 594, 3 N.E. (2d) 102.

31 (1895) 35 N. Y.S. 390,89 Hun. 465.

However, see lilly v. Schmock, supra note 13 , wherein the court went even furtherthan the Gaines case, holding that a joint tenancy had heen created merely because of the use of the words "either-or" in the light of the surrounding circumstances, although the lease did not state that there was any joint tenancy as to the contents of the box.m 
the parties joint access to the box. No other cases have been found on this exact phase of the subject, e.g., where the rental agreement expressly states "joint temants as to the contents", and there are no state statutes authorizing the use of this form of card, as was found in the case of the joint accessicard.

Circumstantial evidence: The reliance by the court upon the bank clerk's explanation, referred to above, raises a strbtle issue. An in quiry as to the ideas of safe deposit clerks in warious banks in the Bay area was undertaken by the writer. Not one of them could teill the incidents of a joint tenancy. Many of them did not know that a will could not be made or that the parties presentily had an equal title and equal interest in the property. ${ }^{32}$ Even the clerE's explanation to Mr. Games on which the court rested its decision, that fre knew the consequences of his acts, was inaccurate. The clerk statedi that upon the decease of one party, the contents belonged to the other. This is conly a half-truth, for what really happened was that upom signing the card, the contents belonged to the other party immediately, so that the title did not pass upon the decease of one of the terrants, for legally the survivor is considered to have always had the tittle subject to the rights of survivorship in the other. ${ }^{33}$ Thus, the Gaines case is the typical example of how unwary persons may become joint tenants without intending it or realizing what it really means.

Advantages and disadvantages of joint tenancy: Joint tenancies. were early favored at common law because the right of survivorship lessened feudal burdens. ${ }^{34}$ Since that period has passed, it has tended to become disfavored because it defeats the passing of any interest in the property by will or by inheritance to one's spouse, heirs, or next of kin. ${ }^{35}$ Many states have abolished joint tenancy or the incident of survivorship by legislation. ${ }^{36}$ In California there must be an express declaration of joint tenancy in the instrument of creation. ${ }^{3 \tau}$ The principal advantages of joint tenancy is recognized as the avoidance of probate proceedings and the expenditure of time and money

32 It is to be noted that there are, in addition to the bank (vault) clerks, managers of the safe deposit vaults in the main branches of the various banks who have a slight acquaintance with the problems involved through discussions at periodic meetings of a national safe deposit. For example, they are familiar with the issue raised in the Young case, but not with the legal explanation. These managers are few in comparison with the number of bank clerks who serve the public daily.

33 See Estate of Gurnsey (1918) 177 Cal. 211, 170 Pac. 402.

342 Tiffany, Real Property (3d ed. 1939) \$426.

35 Ibid.

36 See Notes (1942) 21 ORE. L. REv. 159; (1940) 18 TEx. L. Rev. 232 ; (1910) 23 HaRv, L. Rev. 214.

37 Reiss v. Reiss (1941) 45 Cal. App. (2d) 740, 114 P. (2d) 718; Swartzbaugh v. Sampson (1936) 11 Cal. App. (2d) 451, 54 P. (2d) 73. 
incident thereto. Disadvantages may be found in the imposition of the above enumerated taxes. It has also been contended that there should be a quiet title suit where there is a large estate in joint tenancy to clear title to the property and this entails court procedure. ${ }^{38}$ Another objection is that creditors of the decedent are deprived of recourse to his interest in the property. Whether the disadvantages routweigh the advantages in most cases is a debatable and much debated question. ${ }^{30}$ It depends upon the type of estate, the relationship of the parties, and their desires. The incidents of joint tenancy and its dangers are pointed out to show the need of consulting a careful and skilled attorney before putting a title in joint tenancy. The risks involved to laymen through some form of agreement often used by banks as to joint tenancy ownership of the contents of the box are indeed serious.

The banks should be protected in the renting of joint safe deposit boxes and at the same time satisfy their custoiners without leading people unwittingly to becoine joint tenants of the property placed therein. Considering the increasing use of safe deposit boxes since they were introduced some eighty years ago, their method of use is not such a trivial matter that the legislature should neglect this problem. Many states already have some legislation. ${ }^{40}$ Furthermore, the term joint tenancy should be avoided in the renting of boxes. The term is misleading, because the words (joint) renters and (joint) tenants are synonoinous to the layman. Some regulation by the legislature or by carefully drafted standardized agreement annong those in the profession is very much needed.

Louise Carp Gelber.

\footnotetext{
38 Sinclair, The Dangers of Joint Tenancy (May 6, 1940) Barrons' The NatTonal Financlat Weekit 7.

39 (1936) 12 L. A. BAR Ass'N Bows., 6; Riordon, Dangers Involved in the Use of Gift Deeds and Joint Tenancies, CAL. ST. BAR J., 14:290-6; OrLA. ST. BAR J., 10:592-6; Sinclair, loc. cit. supra note 50.

40 See supra notes $17,18,19,20$.
} 